\title{
Social Capital of Beef Cattle Farmers in Sumberwaru Village at Baluran National Park, Situbondo, Indonesia
}

\author{
Siti Azizah, Irfan H. Djunaidi, Jaisy A. Putritamara, Kiki T.N. Siregar and Dede Aprylasari \\ Faculty of Animal Science, Brawijaya University, Malang, Indonesia
}

\begin{abstract}
The role of social capital is no less important than other economic infrastructure, so efforts to build social capital need to be prioritized for the success of economic development. The formation of social capital can contribute to economic development because of the existence of this research. This research was carried out from June 23-July 22, 2021. The method used in this study used descriptive qualitative analysis. Respondents in this study were 20 farmers and two forest rangers in the Baluran National Park conservation area. Data was collected using interviews with questionnaires and direct observation. It was concluded that the elements of participation in a network, reciprocity, trust, social norms, and values showed a fairly strong level. While Proactive action is low because farmers do not accept innovation in feed management technology because of the culture of grazing cattle into the forest. A good cooperation program with Baluran National Park is needed to preserve the forest.
\end{abstract}

Keywords: Social Capital, Farmers, Cattle, Conservation, Baluran National Park

\section{INTRODUCTION}

Qumberwaru Village is a buffer zone for the Baluran National Park. The village has about 4,167 cattle that more than 1,600 of them are grazed to the core zone of Baluran National Park. Group of farmers herding a big number of cattle into the conservation area. The poor forage caused this grazing management inefficient and not profitable as well as causing ecological losses.

As other business, the sustainability of the beef cattle farming requires economic or financial capital (financial capital). However, there is a capital that can be used for investment in the future, which is social capital (Suharto, 2007). The role of social capital is no less important than other economic infrastructure. The formation of social capital can contribute to economic development because of the existence of networks, norms, and trust in it which become social collaboration (coordination and cooperation) for the common interest of an institution (Inayah, 2012).

Social capital in a community, organization, or group is an accumulation of individual capital which is incorporated into collective capital that can be utilized by all community members. Relationship network (relational/network) is a central point in social capital theory, with which the network will be able to provide collective ownership of capital for organizational members Permadi (2002). Leana, et al. (1999) identified organizational social capital as a collective attribute of the number of connections that two or more individuals have in the organization. The main components of social capital are associability and trust.

Social capital is different from other popular terms, namely human capital. In human capital, everything refers to the individual dimension, namely the power and expertise possessed by an individual. In social capital, more emphasis is placed on the potential of groups and patterns of relationships between individuals within a group and between groups with a focus on social networks, norms, values, and mutual trust that are born from group members and become group norms. Social capital is also very close to other social terminology such as what is known as social virtue. The difference between the two lies in the dimensions of the network. Social virtues will be very strong and influential if there is a feeling of attachment to reciprocal relationships in a form of social relationship (Hasbullah, 2006). In this study, social capital was analyzed to see the strength of social solidarity and community participation between farmers and between farmers and cattle owners. The social capital of farmers could indicate the extent to which they can maintain their livestock business which has been detrimental to Baluran National Park. Thus, the purpose of this study was to determine the social capital between farmers and between farmers and livestock owners in Sumberwaru Village.

\section{RESEARCH METHODOLOGY}

\section{Research Location}

This research was conducted on June 23-July 22, 2021. In Sumberwaru Village, Banyuputih District, Situbondo Regency, East Java Province, Indonesia. The selection of Sumberwaru Village as the research location was carried out purposively, this was based on the number of cattle population in Banyuputih District, which was 24,748 heads (BPS, 2017).

\section{Data Collection Technique}

Data collection is done by using questionnaires and direct observation. The informants are four cattle farmers in the Sumberwaru Village and the management of Baluran National Park. 


\section{Data analysis}

The data analysis used is descriptive qualitative by analyzing, describing, and summarizing several conditions from the data collected in the form of interviews and observations of problems that occur in the field.

\section{RESULT AND DISCUSSION}

Sumberwaru village is located at coordinates between 116005' - 116024' east longitude and 8024'-8057' south latitude.

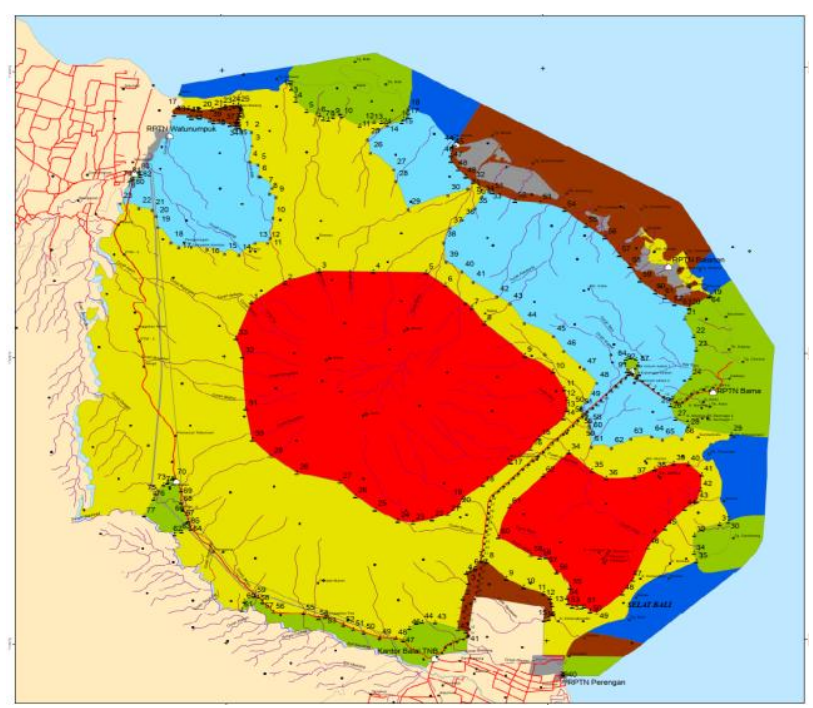

Figure 1. Map of Baluran National Park, Situbondo Regency - East Java Province (2018)

The area of natural resource conservation area of Baluran National Park that has been determined is $\pm 25,000$ ha of land area and 3,750 ha of water area at coordinates $07^{\circ} 29^{\prime} 10^{\prime \prime}$ $07^{\circ} 55^{\prime} 5^{\prime \prime}$ South Latitude and $114^{\circ} 29^{\prime} 20^{\prime \prime}-141^{\circ} 39^{\prime} 10^{\prime \prime}$ East Longitude.

\section{Social Capital}

Social capital is an attribute of individuals and of their relationships that enhance their ability to solve collectiveaction problems (Svendsen \& Svendsen, 2009). This study looks at the strength of the six components of the social capital of cattle breeders in Sumberwaru Village in overcoming economic difficulties and in maintaining cattle in a profit-sharing system.

\section{Participation in a Network}

People always have social relations with other communities through various variations of relationships that are side by side and are carried out on the principles of voluntary, equality, freedom, and civility. The ability of members of the group/community to always unite themselves in a synergistic relationship pattern will have a very large influence in determining whether or not the social capital of a group is strong. Social networks or the presence of emotional closeness between community members such as close friends, relatives, neighbors which are social networks can also lead to closer relationships between villagers in working together. The increase in family economic income is realized through cooperative relationships in herding cattle.

The emergence of social networks creates a strong sense of empathy for the closeness caused when seeing relatives, neighbors, and close relatives experiencing unfavorable economic conditions. This empathy led to the idea of creating a partnership between rich farmers who have a lot of cattle and those who only have a few cattle. Rich farmers who have a lot of cattle give trust to those who have only a few to herd their cattle in the Baluran National Park forest with a profitsharing system. The purpose of this system is to help the poor member of the community by increasing the family's economic income based on the motive of mutual assistance and cooperation. Mubyarto and Kartodiharjo (1990) state that participation is the willingness of the community or farmers to take part in joint activities to support the success of development programs without compromising their interests, starting from the planning, implementation, monitoring, and evaluation stages of development results.

Social networks between farmers and cattle owners are also manifested in livestock and agricultural activities. The land is usually planted with corn and onions using profit sharing with members of community. Seedlings, fertilizers, and equipment were purchased by the cattle owners. People who work as farmers are also included in the social network because the waste from crops, for example, corn husks, is given to their cattle. Usually, a farmer has one to ten cattle (Robbins, 2008).

The strong social capital is caused by cultural similarity because in general, cattle farmers are from the same relative area and ethnicity, namely Madura. They have common interests as immigrant communities who want a better life. Strong social capital will be able to increase the network of cooperation, social relations, and interaction between farmers and groups in seeking more information on innovation, cooperation in farming activities, and application of innovations to increase the production and population of beef cattle. This is in line with what was stated by Fukuyama (2002) which states that by relying on shared norms and values, human relations will result in mutual trust which in turn has great and measurable economic value. Farmers who have strong social capital tend to have more information on innovation so that they have the potential to apply new technology to increase productivity. Strong social capital is indicated by the existence of a fairly extensive network of cooperation, social relations, and interactions between farmers and groups in seeking innovation information, cooperation in farming activities and application of innovations, provision of production facilities, and marketing of products. Unfortunately, the strong relations and interactions between farmers inside the group network not followed by strong relationships with external parties. even though this is expected to strengthen the participation of farmers in developing beef cattle farming businesses to be more productive and provide great benefits for increasing their 
income and welfare. Bolu's research (2011) states the same thing that social capital is an important factor that needs to be considered in agricultural development and rural economic development.

\section{Reciprocity}

The tendency to exchange kindness between individuals within a group or between groups themselves. The pattern of exchange occurs in a combination of long-term and short-term with a feel of altruism without expecting anything in return. In society and social groups that are formed that have strong reciprocity, the weight will give birth to a society that has a strong level of social capital.

Mutual assistance between farmers is usually manifested in activities that help each other to herd cattle in the forest. Farmers divide themselves into groups and take turns herding their cattle in the forest. One group usually consists of six farmers, each group gets a turn to herd once a week. In addition to herding, another task they do is work together to find lost cattle and do not return to the drum in the afternoon. Cattle that do not come home are usually due to illness or giving birth in the forest. If this happens, the group in charge of bringing the cattle home together in a cart. This kind of relationship has become a culture because there is a feeling of comradeship in the same village. Reciprocity is a joint action aimed at giving each other a response. Reciprocity can be found in the form of giving, receiving, helping each other, which can arise from social interactions.

\section{Trust}

A willingness to take risks in social relationships based on a feeling of confidence that the other will do something as expected and will always act in a mutually supportive action pattern. At least, others will not act to the detriment of themselves and their group (Putnam, 1993). Collective action based on mutual trust will increase community participation in various forms and dimensions, especially in the context of mutual progress. This allows communities to come together and contribute to increasing social capital.

High trust among farmers in Sumberwaru Village is shown by entrusting the maintenance of their livestock to other farmers if they have to travel. Feeding and guarding against thief cattle are activities that are generally carried out together without having to provide compensation. Trust is an important component of the existence of a community, and can encourage someone to work together with others to bring up productive activities or joint actions. Trust is a product of very important cooperative social norms which then give rise to social capital. Fukuyama (2002) states trust as expectations for order, honesty, cooperative behavior that arises from within a community based on the norms shared by members of the community. With the trust, cattle rearing activities will continue as usual even though the cattle owners are not present.

\section{Social Norms}

A set of rules that are expected to be obeyed and followed by the community in a particular social entity. These rules are usually institutionalized, unwritten but understood as determining patterns of good behavior in the context of social relations so that there are social sanctions given if violated. Social norms will determine the strength of relationships between individuals because they stimulate social cohesiveness which has a positive impact on community development. Therefore, social norms are referred to as one of social capital. A set of norms and social values in action. Norms are a special identity that can form social capital (social capital). Norms are behavioral guidelines for individuals and what they should do. In addition, norms are a means of maintaining the integrity of the existence of a particular society. A society has a strong existence if they have norms that apply and are mutually agreed upon. Value is something that is appreciated, proud of, upheld, and wants to be obtained by humans in their lives that can develop at any time.

Some of the unwritten norms that apply among beef cattle farmers in Sumberwaru Village are:

1. Legal norms. The responsibility for security in the village must be carried out together, especially from cattle thieves and guarding livestock while grazing. Farmers' activities, both related to beef cattle and personal care, are a shared responsibility.

2. Politeness Norms. Farmers who are included in the village community are very compact in the field of agriculture in planting and harvesting activities which are still cooperation.

3. Moral norms, for example, no immoral activities should be carried out in the forest, the obedience of the younger generation to inherit the beef cattle business, and the democratic nature of parents towards the life choices of the younger generation.

4. Religious norms such as Saturday for praying/istighotsah together, Thursday night filled with the reading of the Qur'an by men, Sunday Pahing (the name of the day in the Javanese calendar) to clean and enliven the mosque, Wednesday afternoon is schedule for reading the Qur'an/khotmil by women, Sunday Pon (name of the day in the Javanese calendar) is reading the Qur'an/khotmil Quran and praying/istighotsah by men. Sholawatan or praising to the Prophet Muhammad is on Friday afternoon and evening.

A set of norms and social values in action. Norms are a special identity that can form social capital (social capital). Norms are behavioral guidelines for individuals and what they should do. In addition, norms are a means of maintaining the integrity of the existence of a particular society. A society will be called strong existence if they have norms that apply and are mutually agreed upon, while value is something that is 
appreciated, proud of, upheld, and wants to be obtained by humans in their lives that can develop at any time.

\section{Values}

An idea that has been passed down from generation to generation is considered correct and important by members of a community group. Value is an important thing in culture, usually, it grows and develops in dominating the lives of certain community groups and influences the rules of action and behavior of people which ultimately form cultural patterns.

A set of values that are still upheld by the farmers of Sumberwaru Village that affect their strong social capital, among others, are the values:

1. cooperation, both in beef cattle raising activities and in other general activities

2. Religion that is routinely done together

3. Moral, keeping the norms prevailing in society upheld

\section{Proactive Action}

The proactive action of farmers in Sumberwaru Village is categorized low. This is indicated by the resistance of farmers to the feed management program and of cattle maintenance that was introduced to them. This is likely due to their reluctance to leave the wild herding culture (extensive management) and the additional cost if they have intensive farming management. Extension program on animal feed management from planting to processing feed did not give benefit because it is difficult to find and to buy feed components since it incurs additional costs. The way to herd and release the cattle into the forest is the easiest because farmers do not have to put extra work to give feed and the cattle are trained to return to the cage by themselves in the afternoon. Low participative action makes the conservation programs are difficult to carried out. As Lurin (2004) to encourage community participation for decision making in local government development.

\section{CONCLUSIONS}

Social capital in the solidarity of cattle farmers in Sumberwaru Village in terms of participation in a network, reciprocity, trust, social norms, and values elements shows a strong level except for proactive action. The culture and extra cost for intensive rearing management make farmers reluctant to cattle feed extension program. Thus it is difficult to implement the Baluran National Park conservation program.

\section{ACKNOWLEDGMENT}

This research was supported/partially supported by Doctoral Grant Program 2021 Universitas Brawijaya. We thank Baluran National Park who provided insight and expertise that greatly assisted the research and the beef cattle farmers in Sumberwaru Village, as well as those who provided a lot of information and collaboration during the research process.

\section{REFERENCES}

[1] Suharto, E. (2007). Social Policy as Public Policy. Bandung: Alphabeta.

[2] Inayah. (2012). The Role of Social Capital in Development. Paper for the Department of Commercial Administration at the Semarang State Polytechnic. Semarang.

[3] Permadi., D. C. (2002). The Influence of Organizational Social Capital and Organizational Intellectual Capital on Organizational Excellence at PT Polysindo Eka Perkasa - PT. Multi KarsaInvestama Kendal. Thesis: Master in Management. Diponogoro University. Semarang.

[4] Leana, C. R., \& Van Buren, H. J. (1999). Organizational Social Capital and Employment Practice. Academy of Management Review. 24(3): 538-555.

[5] Hasbullah, J. (2006). Social Capital (Towards the Excellence of Indonesian Culture). Jakarta. MR-United Press

[6] BPS. (2017). Livestock Population by District and Type of Livestock in Situbondo Regency 2017. Livestock Service Office of Situbondo Regency.

[7] Svendsen, G. T., \& Svendsen, G. L. H. (2009). The troika of sociology, political science and economics. Handbook of Social Capital: The Troika of Sociology, Political Science and Economics, 1-13. https://doi.org/10.4337/97818484474866.00006

[8] Mubyarto \& Kartodihardjo, (1990). Rural Development in Indonesia. Liberty, Jakarta.

[9] Robbins, S. (2008). Organizational Behavior, Volumes I and II, translated: Hadyana Pujaatmaja. Jakarta: Prenhallindo.

[10] Fukuyama, F. (2002). The Great Disruption: Human Nature and the Reconstruction of Social Order. Yogyakarta : CV Qalam.

[11] Bolu, Y.G. (2011). A Study of the Effect of Social Capital and Information Disclosure of Innovations on the Level of Corn Innovation Adoption in East Lombok Regency. Dissertation. UGM Graduate School, Yogyakarta.Carpenter SR, Brock WA. 2004. Spatial Complexity, Resilience and Policy Diversity: Fishing on Lake-rich Landscapes. Ecology and Society. 9(1):8.

[12] Putnam, R. (1993). The Prosperous Community: Social Capital and Public Life. The American Prospect,13 (Spring 1993) 4: 3542.

[13] Lurin, L. (2004). Public Participation in Environmental Decission Making Finding For Communities Facing Toxic Waste Cleanup. Journal of American Planning Association. Chicago, Vol. 70 No. 1 2004. 